Article

\title{
Locally Grown Foods and Farmers Markets: Consumer Attitudes and Behaviors
}

\author{
David Conner $^{1}{ }^{1}$, Kathryn Colasanti ${ }^{1}$, R. Brent Ross ${ }^{2}$ and Susan B. Smalley ${ }^{1}$
}

1 C.S. Mott Group for Sustainable Food Systems, Department of Community, Agriculture, Recreation and Resource Studies, Michigan State University, 131 Natural Resources Building, East Lansing, MI 48824, USA; E-Mails: colokat@msu.edu (K.C.); smalley3@msu.edu (S.B.S.)

2 Department of Agricultural, Food, and Resource Economics, Michigan State University, 202 Agriculture Hall, East Lansing MI 48824, USA; E-Mail: rross@msu.edu

* Author to whom correspondence should be addressed; E-Mail: connerd@msu.edu; Tel.: +1-517-353-1914; Fax: +1-517-353-3834.

Received: 9 February 2010; in revised form: 4 March 2010 / Accepted: 10 March 2010 / Published: 12 March 2010

\begin{abstract}
Farm viability poses a grave challenge to the sustainability of agriculture and food systems: the number of acres in production continues to decline as the majority of farms earn negative net income. Two related and often overlapping marketing strategies, (i) locally grown foods and (ii) distribution at farmers markets, can directly enhance food system sustainability by improving farm profitability and long-term viability, as well as contributing to an array of ancillary benefits. We present results of a representative Michigan telephone survey, which measured consumers' perceptions and behaviors around local foods and farmers markets. We discuss the implications of our findings on greater farm profitability. We conclude with suggestions for future research to enhance the contributions of locally grown foods and farmers markets to overall food system sustainability.
\end{abstract}

Keywords: Michigan; Probit analysis; marketing strategies 


\section{Introduction}

Farm profitability continues to be of grave concern for many US and Michigan farmers. According to the Census of Agriculture, more than half of all farms in both the US and Michigan experienced negative net income in 2002 and 2007 [1]. Coinciding with this finding, acreage dedicated to farming has also continued to decline during this period. Both trends are occurring in a time of renewed interest in the sustainability of agriculture and food systems. Sustainability has classically been described as having three legs or pillars (social, environmental and economic), yet meeting these three categories of goals can require tradeoffs. For example, more environmentally friendly production methods may cost more, limiting farmer profits or low income people's access to food products. Maintaining relationships with customers presents an opportunity cost on farmers' time. In these cases, some sort of economic compensation is needed if sustainable practices are to be adopted and maintained.

The issue of farm viability is particularly acute in light of the threat to farmland on the urban fringe, which contributes the majority of dairy and produce production in the US; these foods are associated with healthful diets and are often lacking in American diets [2,3]. For these and other reasons, a sustainable food and agriculture system requires economically viable farms and productive farmland to provide quality food. Numerous other studies have linked community economic and social well-being with the presence of farms of diverse scales [4-6]. In particular, medium-sized, owner-operated, entrepreneurial farms have been found to be important in sustaining community well-being, yet this type of farm is the most imperiled [7].

Two related marketing strategies, (i) locally grown foods (differentiated by the location where foods are grown or raised relative to where they are sold) and (ii) farmers markets (differentiated by where and how foods are sold; providing opportunities to sell locally-grown foods but may also sell other foods), can enhance food system sustainability by providing market opportunities and price premiums for small and medium sized farms [8,9]. Interest in and demand for locally grown foods has risen dramatically in recent years. Marketing products to those who derive utility from the "locally grown" attribute contributes to a product differentiation strategy (rather than a high volume low cost strategy employed by most commodity farmers) in the marketplace [10,11]. Distribution through farmers markets has also become a popular marketing strategy in recent years. Distribution through this marketing channel has increased nearly threefold in the past eight years both in Michigan and Nationwide [12]. Farmers markets offer farmers the opportunity to meet demand for locally grown food products as well as gain nearly $100 \%$ of the consumers' food dollar (compared to about one-fifth of the food dollar accruing to farmers in the aggregate), while reducing certain marketing costs $[8,13]$. Farmers markets and other direct marketing options may also increase customer loyalty and create non-economic ties between farmers and eaters [8,14].

Locally grown foods and farmers markets also contribute to the sustainability of the food system in ways beyond fostering farm viability. Research from Michigan and Iowa finds significant job and income impacts resulting from increased consumption of locally grown produce $[3,15]$. Locally grown foods play a central role in community-based food systems, which can contribute to a wide array of related economic, social, land use and public health benefits [16]. Farmers markets can bring a host of ancillary benefits as well, serving as business incubators, drawing customers to downtown areas and increasing access to healthy foods [17,18]. Given the importance of locally grown product 
differentiation and direct market sales to small and medium-sized farm viability, it is crucial to understand consumer perspectives on these market attributes and venues [8].

Adopting marketing strategies for locally grown products and farmers markets sales also has budgetary implications. For many farms and farmers market managers (especially those of small and medium scale), marketing budgets are likely to be quite limited, increasing the need for well-targeted promotional and marketing efforts. Demographically-based market segmentation is one of the most commonly touted market segmentation practices. [19]. A nationwide study of direct market produce posited an ideal marketing strategy which highlights food quality (including "locally grown") attributes, yet lowers transaction costs to enhance convenience [14]. This strategy may require tradeoffs [8]: for example, a farmers market may find it difficult to be open every day, and seasonality limits the availability of many types of locally grown produce. Hinrichs discusses similar tradeoffs as the tensions between "embeddedness" and "marketness and instrumentalism" in local food systems [20]. "Embeddedness, in this sense of social connection, reciprocity and trust, is often seen as the hallmark (and comparative advantage) of direct agricultural markets", Hinrichs writes (p. 296). Similarly, "marketness expresses the relevance of price in the transaction", while "instrumentalism occurs when actors prioritize economic goals", (p. 297). Hinrichs concludes that "recognizing how social embeddedness is qualified by marketness and instrumentalism is critical for understanding the viability, development and outcomes of local food systems", (p. 301). While, admittedly, not all aspects of marketing strategy fit neatly into these categories, this framework highlights the types of potentially difficult tradeoffs a farmer utilizing local and direct markets would face.

Numerous studies have documented the demographic characteristics, as well as motivations, behaviors and preferences of farmers market and local food shoppers. Previous research has identified several demographic variables associated with farmers market patronage: farmers market shoppers tend to be older, female, married, employed, live in urban areas and have higher levels of education and income [21-24]. One study with a nationwide sample found that those who frequently buy fresh produce directly from farmers place high value on product quality, freshness and safety, as well as organic and locally grown products [14]. Direct market customers in Washington State valued food quality and freshness most highly [25]. Farmers market shoppers in North Carolina and New Jersey placed high value on fresh, high quality, local farm products and a positive atmosphere [8,9]. A nationwide survey on local food consumption found that knowledge and attitudes about food and shopping behavior, rather than demographics or health and environmental attitudes, influenced local food purchases [26]. Most Ohio consumers had purchased locally grown food and expressed support for efforts to strengthen local food systems [27]. We know of no similar study on local food or farmers market shopping in Michigan, nor any study which measures how demographic variables influence attitudes and preferences for local food and farmers markets.

Preliminary findings and other evidence from Michigan suggest that different ethnic groups have different perspectives of farmers markets, from both vendor and customer viewpoints. Michigan State University Extension Educator Juan Marinez, who works closely with Latino farmers, says that Latino farmers commonly express perceptions such as feeling unwelcome and experiencing discrimination (e.g., stall allocation) as farmers market vendors [28]. Latina women participating in a Michigan consumer focus group about farmers markets expressed feeling unwelcome and felt they were viewed with suspicion by vendors and other customers. Such sentiments were not expressed by other similar 
consumer focus groups, including one held in the same community on the same day with white participants [29]. These experiences in Michigan reinforce prior studies and reports which suggest the preponderance of white and higher class values in the way farmers markets are organized and managed [30-32].

One approach that market managers and stakeholders have used to gather information is Rapid Market Assessment (RMA), a set of techniques pioneered by Oregon State University researchers [33]. The Michigan Farmers Market Association and Michigan State University conducted these studies in 24 Michigan farmers markets from 2005-2008. Data gathering techniques included (i) dot poster surveys, (ii) customer counts and (iii) constructive comments and observations. Data from RMAs have been used to improve market appearance and management, and to demonstrate local economic impact. While the results of RMAs provide useful departure points for research, they represent only a small fraction of Michigan farmers markets and, most importantly, represent only the responses of those attending the markets on the days of the assessments. Such indications of a range of perspectives, along with the limited scope of RMA-based research, point to a need for research that represents a broader cross-section of the population.

This paper reports on results of a representative statewide telephone survey in Michigan which measured consumers' attitudes and behaviors surrounding locally grown foods and farmers markets. Our objectives were to identify opportunities and obstacles which inform marketing strategies for local food and farmers markets and reflect the demographic diversity of the state, including both those who do and do not purchase locally grown food or shop at farmers markets. We acknowledge a potentially large degree of overlap between these two behaviors, (buying locally grown food and shopping at farmers markets), given that farmers markets are an important outlet for local products; however, we present the results as those of two potentially distinct strategies to accommodate those interested in either one alone. We recognize that shoppers can purchase local foods in venues outside farmers markets and that not all farmers markets sell only local foods. Of particular interest are demographic differences in perceptions surrounding marketness/embeddedness-instrumentalism tradeoffs and how these influence shopping behavior. The following sections will discuss the methods employed to collect and analyze data, results of the survey, and implications for marketing strategies.

\section{Methods}

The data for this study were obtained from a statewide telephone survey of Michigan residents, the Fall 2008 State of the State Poll conducted by Michigan State University's Institute for Public Policy and Survey Research [34]. This quarterly poll consists of a series of recurring demographic questions (including age, sex, income, etc., as well as political and religious affiliations) in addition to questions commissioned by MSU researchers and other stakeholders. A list of variables, their definitions and mean values are detailed in Table 1.

The referent population is the non-institutionalized, English-speaking adult population of Michigan, age 18 and over. Since the survey was conducted by telephone, only persons who lived in households with landline telephones had a chance of being interviewed. The sample is weighted to be representative of state residents. A total of 953 interviews were completed in October 2008 [34]. 
The questions for this study asked respondents about shopping behavior and attitudes, including those surrounding farmers markets and locally grown foods. First, respondents were asked how frequently they shop for food for their household; those answering "never" (10\% of respondents) were diverted to the next part of the survey and answered no further questions pertaining to farmers markets or locally grown foods.

The succeeding questions pertained to farmers markets. Respondents were provided with the definition "a farmer's market is a place where a group of farmers come together, usually once a week, to sell their farm products", and asked if they had attended one in the past year. Next, a set of questions measured the importance of twelve factors in the consumers' decisions to shop at a farmers market using a four point Likert-type scale. The content of these questions emerged from factors commonly driving shopping behavior, previous research on farmers markets and results from a series of focus groups in Michigan which sought to identify barriers to farmers market patronage by under-represented populations [29]. A dummy attitudinal variable was created for each, equaling 1 if the response was "very important", 0 for other responses (somewhat, not very or not at all).

Questions on locally grown foods followed a slightly different pattern. Respondents were given a list of possible definitions of locally grown foods (See Figure 1), guided by previous research [35-37], then asked if they had bought locally grown food in the previous calendar month. Finally, they were given a set of two potential opportunities for (increased availability and greater ability to identity) and five barriers to (high cost; unimportance; lack of time; lack of preparation skill; and inability to find) local food purchases and asked to express their agreement with each statement on a five point Likert-type scale (See Table 1).

A series of ordered Probit and binary Probit analyses were conducted to model the relationships between (i) demographic factors (the independent variables) and (ii) farmers market drivers, local food opportunities and barriers, and local/farmers market shopping behaviors (all dependent variables). Binary probit measures the effect of the independent variables on the probability of the respondent having behaved in a certain way (in this case, having shopped at a farmers market or bought local food). Ordered Probit allows for analysis of multiple but discrete values of the dependent variable while maintaining the ordinal nature (in this case that "very" is more important than "somewhat", and so on). A positive sign on the coefficient of a given independent variable implies greater likelihood that respondents in this category answered affirmatively to the behavior in question (in binary probit) or valued a given attribute more highly (in ordered probit). As examples of (i) binary and (ii) ordered probit results, a positive coefficient for "white" implies that a white person is more likely (compared to other ethnicities) to (i) have shopped at farmers markets and (ii) express greater importance of supporting local farmers.

The twelve factors driving farmers market patronage and the seven potential local food opportunities and barriers were regressed on the demographic variables using an ordered Probit model. The objective was to discover variations in responses according to demographic factors. In our analysis, the farmers market drivers were divided into two groups: those variables representing factors generally associated with all shopping behavior like convenience and value (roughly corresponding to Hinrichs' "marketness and instrumentalism" concepts), and those particularly associated with reasons to shop at farmers markets like finding local food and the congenial atmosphere (Hinrichs" "embeddedness") [20] . 
Both behavioral variables (whether one had (i) shopped at a farmers market and (ii) bought local) were analyzed using a binary Probit model, regressed on the demographic variables and a series of dummy attitudinal variables equaling 1 if the response was "very important", 0 for other responses (somewhat, not very or not at all). In all ordered and binary Probit analyses, restricted models limited to regressors with $\mathrm{Z}$ or $\mathrm{T}$ values greater than one were also calculated. Log likelihood tests recommended the use of full models in all cases.

\section{Results}

\subsection{Descriptive Statistics, Farmers Markets}

Over half of respondents $(61 \%)$ stated they had visited a farmers market in the past year, averaging four visits in the most recent calendar month. The factors with the highest mean importance for shopping at farmers markets were food quality (3.80), safety from food borne illness (3.75) and ability to support local farms (3.70). The least important factors (lowest mean response) were availability of pesticide-free (2.98) and hormone-free (3.07) food products and ability to do one stop shopping (3.08). The mean values of several key demographic and behavioral variables are available in Table 1 . The mean values of attitudes related to (1) farmers market participation and (2) local food purchases are shown in Figures 1 and 2, respectively.

Table 1. Descriptive statistics: shoppers surveyed and farmers markets.

\begin{tabular}{ll}
\hline Shopper Demographics & Shopper Behavior \\
\hline $\begin{array}{l}\text { 53\% Female } \\
\text { Mean. age = 46 years }\end{array}$ & $\begin{array}{l}61 \% \text { shopped at farmers markets } \\
\text { in the past year }\end{array}$ \\
$\begin{array}{l}\text { Mean. no. adults in household }=2.39 \\
\text { Mean. no. children in household }=0.91\end{array}$ & $\begin{array}{l}75 \% \text { bought locally grown food in the } \\
\text { past year }\end{array}$ \\
$\begin{array}{l}\text { Median education level = some college } \\
61 \% \text { Married, } 22 \% \text { Single }\end{array}$ & \\
$38 \%$ work full time, $19 \%$ work part time, $17 \%$ retired & \\
$5 \%$ Latino, $13 \%$ African-American, $81 \%$ White & \\
\hline
\end{tabular}

\subsection{Descriptive Statistics, Locally Grown Foods}

Almost half (49\%) of respondents defined "locally grown foods" as those grown in Michigan, while about $18 \%$ each defined local as grown in the Great Lakes region or within 100 miles from home (Figure 3). Knowing the farmer who grows it was the least common answer (4\%). These results are in line with previous studies finding state boundaries and distance from home as important definitions of local [36,37].

Almost three-fourths (74.8\%) of survey respondents stated they had purchased locally grown foods in the previous calendar month. The ability to better identify locally grown food held the greatest opportunity for increasing local food purchases (mean 4.33), while the greatest barrier was lack of 
availability (3.51). Interestingly, very few respondents saw an increased cost of local food as a major barrier (mean 2.35).

Figure 1. Mean importance of various factors in decision whether or not to shop at a farmers market.

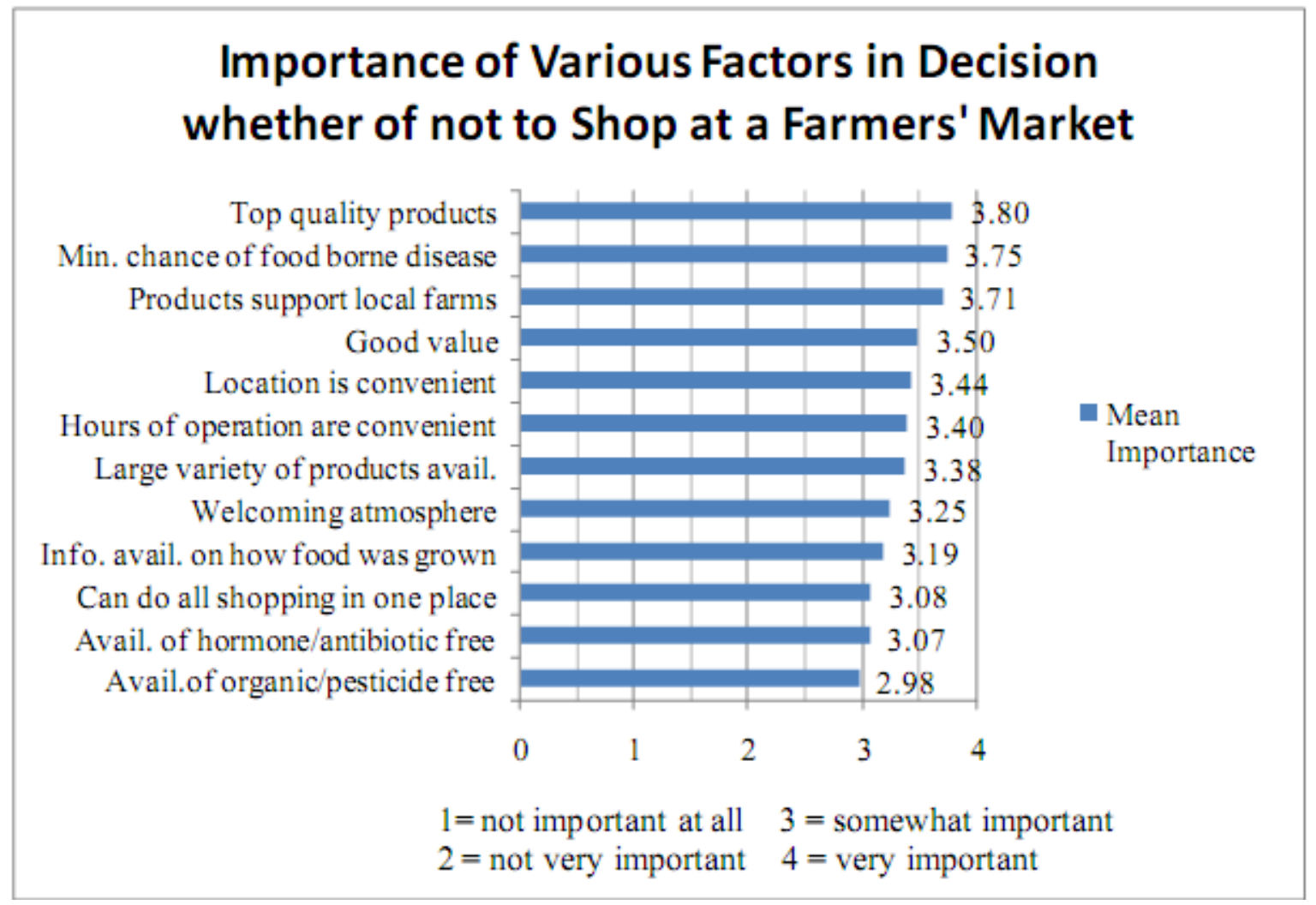

Figure 2. Mean agreement with statements about locally-grown foods.

\section{Attitudes and Perceptions of Locally-grown foods}

Would buy more if easier to identify

Currently avail. at places I like to shop

Can't find kinds I want when I want them

Doesn't matter to me

Don't use because don't know how to prepare

Don't have time to shop for

Cost too much

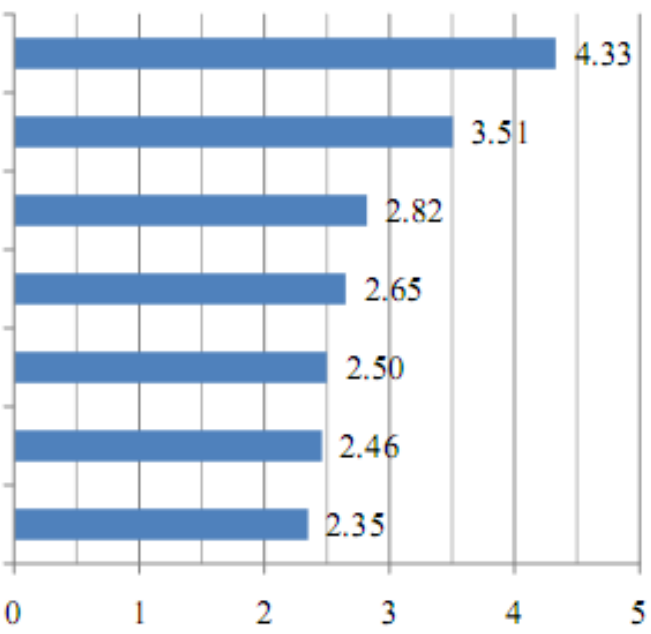

mean

Agreement

$1=$ strongly disagree $2=$ somewhat disagree $3=$ neither agree nor disagree $4=$ somewhat agree $\quad 5=$ strongly agree 
Figure 3. Respondent definitions of "Locally Grown".



\subsection{Ordered Probit Results, Farmers Markets}

People who were white and had higher incomes generally placed lower importance on factors associated with value and convenience factors, while Latinos and those working part time were more likely to value these factors (Table 2; note: for space considerations, only variables with significant coefficients are presented in this table). Interestingly, Latinos were also more likely to value certain local-specialty attributes like hormone-free animal products and access to information about how food was produced (Table 3 ).

Table 2. Coefficient (standard error) for ordered Probit analyses of standard shopping attitude variables.

\begin{tabular}{|c|c|c|c|c|c|c|}
\hline \multirow[b]{3}{*}{ Value } & \multicolumn{6}{|c|}{ Variable Coefficient (Standard Error) } \\
\hline & \multicolumn{3}{|c|}{ Positive Correlation } & \multicolumn{3}{|c|}{ Negative Correlation } \\
\hline & $\begin{array}{l}\text { Full time } \\
0.428^{*} \\
(0.225)\end{array}$ & $\begin{array}{l}\text { Afr-Amer } \\
0.971^{* *} \\
(0.417)\end{array}$ & $\begin{array}{l}\text { Part time } \\
0.724 * * * \\
(0.279) \\
\text { Retired } \\
0.708 * * * \\
(0.268)\end{array}$ & $\begin{array}{l}\text { Single } \\
-0.554 * * \\
(0.259)\end{array}$ & $\begin{array}{l}\text { Age } \\
-0.20 * * * \\
(0.007)\end{array}$ & $\begin{array}{l}\text { Income } \\
-0.013 * * * \\
(0.004)\end{array}$ \\
\hline Location & & $\begin{array}{l}\text { Age } \\
0.22 * * \\
(0.009) \\
\end{array}$ & & $\begin{array}{l}\text { Retired } \\
-0.647 * * \\
(0.284) \\
\end{array}$ & $\begin{array}{l}\text { White } \\
-0.917^{* * *} \\
(0.290) \\
\end{array}$ & $\begin{array}{l}\text { Afr-Amer } \\
-0.985^{* * *} \\
(0.319)\end{array}$ \\
\hline Hours & $\begin{array}{l}\text { Latino } \\
0.817 * \\
(0.432) \\
\end{array}$ & $\begin{array}{l}\text { Female } \\
0.409 * * \\
(0.165) \\
\end{array}$ & $\begin{array}{l}\text { Education } \\
0.103 * * * \\
(0.039) \\
\end{array}$ & & $\begin{array}{l}\text { Income } \\
-0.011 * * \\
(0.004) \\
\end{array}$ & $\begin{array}{l}\text { White } \\
-0.998 * * * \\
(0.244)\end{array}$ \\
\hline One Stop & $\begin{array}{l}\text { Latino } \\
1.025^{*} \\
(0.554) \\
\end{array}$ & & & $\begin{array}{l}\text { Income } \\
-0.008 * * \\
(0.004)\end{array}$ & $\begin{array}{l}\text { Age } \\
-0.017 * * \\
(0.007) \\
\end{array}$ & $\begin{array}{l}\text { Education } \\
-0.102 * * * \\
(0.034)\end{array}$ \\
\hline
\end{tabular}


Table 2. Cont.

\begin{tabular}{|c|c|c|c|c|c|}
\hline & \multicolumn{5}{|c|}{ Variable Coefficient (Standard Error) } \\
\hline & \multicolumn{3}{|c|}{ Positive Correlation } & \multicolumn{2}{|c|}{ Negative Correlation } \\
\hline Food & Education & No. of & Female & White & Income \\
\hline Borne & $0.090 * *$ & Adults & $0.540 * * *$ & $-0.722 *$ & $-0.009 * *$ \\
\hline \multirow[t]{5}{*}{ Disease } & $(0.040)$ & $0.382 * * *$ & $(0.182)$ & $(0.375)$ & $(0.004)$ \\
\hline & & $(0.121)$ & & & \\
\hline & & Retired & Part time & & \\
\hline & & $0.720 * * *$ & $0.767 * * *$ & & \\
\hline & & $(0.273)$ & $(0.264)$ & & \\
\hline
\end{tabular}

Note: One, two and three asterisks $(*)$ denote significance at the $0.10,0.05$ and 0.01 levels respectively.

Table 3. Coefficient (standard error) for ordered Probit analyses of local/specialty food variables.

\begin{tabular}{|c|c|c|c|c|c|c|}
\hline & \multicolumn{6}{|c|}{ Variable Coefficient (Standard Error) } \\
\hline & \multicolumn{3}{|c|}{ Positive Correlation } & \multicolumn{3}{|c|}{ Negative Correlation } \\
\hline Quality & & & $\begin{array}{l}\text { No. of } \\
\text { Adults } \\
0.337^{* * *} \\
(0.127) \\
\end{array}$ & & $\begin{array}{l}\text { White } \\
-0.884 * * \\
(0.357)\end{array}$ & \\
\hline $\begin{array}{l}\text { Local } \\
\text { Farm }\end{array}$ & $\begin{array}{l}\text { White } \\
0.632 * \\
(0.355) \\
\end{array}$ & $\begin{array}{l}\text { Female } \\
0.377 * * \\
(0.186) \\
\end{array}$ & $\begin{array}{l}\text { Retired } \\
0.525^{* *} \\
(0.249) \\
\end{array}$ & & & $\begin{array}{l}\text { Age } \\
0.025 * * * \\
(0.007) \\
\end{array}$ \\
\hline Info & & & $\begin{array}{l}\text { Latino } \\
1.588 * * * \\
(0.573) \\
\end{array}$ & & & \\
\hline $\begin{array}{l}\text { Hormone } \\
\text { Free }\end{array}$ & 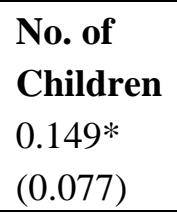 & $\begin{array}{l}\text { Latino } \\
0.603^{*} \\
(0.362)\end{array}$ & $\begin{array}{l}\text { Afr-Amer } \\
0.804 * \\
(0.454)\end{array}$ & $\begin{array}{l}\text { Education } \\
-0.080^{* *} \\
(0.33)\end{array}$ & $\begin{array}{l}\text { Full time } \\
-0.455^{* *} \\
(0.216)\end{array}$ & $\begin{array}{l}\text { Part time } \\
-0.476^{* *} \\
(0.227)\end{array}$ \\
\hline Welcome & $\begin{array}{l}\text { Single } \\
0.468 * \\
(0.283)\end{array}$ & $\begin{array}{l}\text { Latino } \\
0.864 * \\
(0.491)\end{array}$ & $\begin{array}{l}\text { No. of } \\
\text { Adults } \\
0.217 * * \\
(0.107) \\
\end{array}$ & & $\begin{array}{l}\text { Afr-Amer } \\
-0.984 * * * \\
(0.317)\end{array}$ & $\begin{array}{l}\text { White } \\
-1.135^{* * *} \\
(0.281)\end{array}$ \\
\hline Variety & $\begin{array}{l}\text { Part time } \\
0.446^{*} \\
(0.244)\end{array}$ & $\begin{array}{l}\text { Income } \\
0.008 * * \\
(0.004)\end{array}$ & $\begin{array}{l}\text { Latino } \\
0.981 * * \\
(0.489)\end{array}$ & $\begin{array}{l}\text { Single } \\
-0.474 * \\
(0.265)\end{array}$ & $\begin{array}{l}\text { White } \\
-0.556^{*} \\
(0.333)\end{array}$ & $\begin{array}{l}\text { Education } \\
-0.082 * * \\
(0.036) \\
\text { Married } \\
-0.453 * * \\
(0.218) \\
\end{array}$ \\
\hline
\end{tabular}

Note: One, two and three asterisks $(*)$ denote significance at the $0.10,0.05$ and 0.01 levels respectively. 


\subsection{Ordered Probit, Local Food}

None of the demographic variables were significant for both the opportunities and barriers to local food purchase variables. With respect to the opportunity variables (i.e., available, identify), respondents identifying themselves as Latino or married increased the likelihood of buying more local if available and able to identify, while working part- or full-time and being retired all decreased the importance of being able to identify locally grown foods (Table 4).

Table 4. Coefficient (standard error) for ordered Probit analyses of opportunities/barriers to local food purchase.

\begin{tabular}{|c|c|c|c|c|c|c|}
\hline & \multicolumn{6}{|c|}{ Variable Coefficient (Standard Error) } \\
\hline & \multicolumn{3}{|c|}{ Positive Correlation } & \multicolumn{3}{|c|}{ Negative Correlation } \\
\hline $\begin{array}{l}\text { Are Available } \\
\text { Where I Shop }\end{array}$ & & $\begin{array}{l}\text { Married } \\
0.402 * * \\
(0.187) \\
\end{array}$ & & & & $\begin{array}{l}\text { White } \\
-0.643^{* * *} \\
(0.234)\end{array}$ \\
\hline $\begin{array}{l}\text { Would Buy } \\
\text { More if Could } \\
\text { Identify }\end{array}$ & & $\begin{array}{l}\text { Latino } \\
1.257 * * \\
(0.575)\end{array}$ & & $\begin{array}{l}\text { Female } \\
-0.308 * \\
(0.163)\end{array}$ & $\begin{array}{l}\text { Retired } \\
-0.502 * \\
(0.281)\end{array}$ & $\begin{array}{l}\text { Part time } \\
-0.536^{* *} \\
(0.272) \\
\text { Full time } \\
-0.575^{* *} \\
(0.246) \\
\end{array}$ \\
\hline No Time & $\begin{array}{l}\text { Income } \\
0.007 * \\
(0.004) \\
\end{array}$ & & & $\begin{array}{l}\text { Married } \\
-0.328 * \\
(0.189) \\
\end{array}$ & & \\
\hline Can't Find & & & & $\begin{array}{l}\text { Retired } \\
-0.409 * \\
(0.222)\end{array}$ & $\begin{array}{l}\text { Female } \\
-0.416^{* *} \\
(0.169) \\
\end{array}$ & \\
\hline $\begin{array}{l}\text { Don't Know } \\
\text { How to Prepare }\end{array}$ & & & & $\begin{array}{l}\text { Income } \\
-0.007 * \\
(0.003) \\
\end{array}$ & $\begin{array}{l}\text { Afr-Amer } \\
-1.014^{* *} \\
(0.397) \\
\end{array}$ & \\
\hline Cost Too Much & & $\begin{array}{l}\text { No. of } \\
\text { Children } \\
0.138^{* *} \\
(0.070) \\
\end{array}$ & $\begin{array}{l}\text { Latino } \\
1.004 * * \\
(0.454)\end{array}$ & $\begin{array}{l}\text { Married } \\
-0.326^{*} \\
(0.177)\end{array}$ & $\begin{array}{l}\text { Full time } \\
-0.392 * * \\
(0.191)\end{array}$ & $\begin{array}{l}\text { Part time } \\
-0.555^{* *} \\
(0.257)\end{array}$ \\
\hline Doesn't Matter & $\begin{array}{l}\text { Part time } \\
0.509 * \\
(0.260)\end{array}$ & & & $\begin{array}{l}\text { Education } \\
-0.062 * * \\
(0.032)\end{array}$ & $\begin{array}{l}\text { No. of } \\
\text { Adults } \\
-0.170^{* *} \\
(0.070) \\
\end{array}$ & $\begin{array}{l}\text { Female } \\
-0.460 * * * \\
(0.164)\end{array}$ \\
\hline
\end{tabular}

Note: One, two and three asterisks $(*)$ denote significance at the $0.10,0.05$ and 0.01 levels respectively.

\subsection{Binary Probit, Farmers Market Participation}

Four variables were statistically significant at the .10 level or higher, with positive sign (Table 5): importance of food quality and importance of supporting local farms as well as being white, and single 
all had a positive effect on farmers market attendance. Four variables were significant with negative sign: importance of one stop shopping and convenient hours, Latino ethnicity and working part time.

Table 5. Binary Probit analysis of farmers market attendance.

\begin{tabular}{lc}
\hline Variable Name & $\begin{array}{c}\text { Coefficient } \\
\text { (Standard Error) }\end{array}$ \\
\hline Positive Correlation & \\
\hline Supporting local farms is & $0.43^{*}(0.23)$ \\
very important & $0.50^{*}(0.28)$ \\
Quality is very important & $0.59^{* *}(0.29)$ \\
White & $0.65^{* *}(0.31)$ \\
Single & \\
\hline Negative Correlation & $-0.58^{*}(0.31)$ \\
\hline Works part time & $-0.97 * *(0.48)$ \\
Latino & $-0.62^{* * *}(0.20)$ \\
One stop shopping is very important & $-0.83^{* * *}(0.23)$ \\
Convenience is very important & $-1.91^{* *}(0.90)$ \\
\hline Constant & \\
\hline
\end{tabular}

Note: One, two and three asterisks $(*)$ denote significance at the $0.10,0.05$ and 0.01 levels respectively.

\subsection{Probit, Local Food Purchase}

Three of the opportunity/barrier variables were significant in local food purchases (Table 6). Those who said local does not matter were less likely to buy, as were those who would buy more if able to identify. Curiously, those who claimed to lack skill in preparing local foods were more likely to buy. Two demographic variables were significant, all with positive sign: the number of adults in household and working part time.

Table 6. Binary Probit analysis of local food purchase.

\begin{tabular}{lc}
\hline Variable Name & $\begin{array}{c}\text { Coefficient } \\
\text { (Standard error) }\end{array}$ \\
\hline Positive Correlation & \\
\hline No. of adults & $0.238^{*}(0.125)$ \\
Don't know how to prepare & $0.349^{*}(0.202)$ \\
local foods & $0.673^{* *}(0.342)$ \\
\hline Works part time & \\
\hline Negative Correlation & $-0.390^{*}(0.216)$ \\
\hline Local food doesn't matter & $-0.842 * *(0.278)$ \\
Would buy more local food if & \\
\hline Constant identify & $-1.914 * *(.893)$ \\
\hline
\end{tabular}

Note: One, two and three asterisks $(*)$ denote significance at the $0.10,0.05$ and 0.01 levels respectively. 


\section{Discussion}

Viable farms are an indispensible piece of sustainable food systems. Two related marketing strategies, (i) locally grown foods and (ii) distribution at farmers markets, can enhance farm profitability and keep land in productive agricultural uses, as well as foster a host of community economic benefits. A random telephone survey of Michigan residents finds high current participation in farmers markets, driven in part by demand for high quality locally grown foods, and constrained by lack of convenience. Most Michigan residents have bought locally grown foods in the past year, with the ability to identify local foods a significant constraint to greater sales. These results further emphasize the difficult tradeoffs between attributes associated with all purchases (e.g., price, convenience) versus those more closely associated with local food and farmers markets (e.g., locally grown and relationships with local farmers), as highlighted by Hinrichs' discussion of embeddedness and marketness-instrumentalism [20]. Furthermore, relative importance of these attributes varies widely among different demographic groups and appears to affect consumer participation in these markets.

These results suggest several key marketing strategies which would foster greater patronage of farmers markets and purchases of locally grown food. First, despite broad reported farmers market participation, these results show profound differences in the attitudes and behaviors of Latinos, confirming previous observations and research discussed above. Latinos place high value on the variety of products available (especially hormone-free animal products) and having access to information on how and where the food was produced, yet the lack of a welcoming atmosphere appears to be a major constraint. Making farmers markets more welcoming to Latinos, including using Spanish language advertisements, signs and labels and recruiting and supporting more Latino farmer-vendors, would foster greater participation, as would training programs for vendors which would help them understand Latino customers and forge better relationships.

Second, efforts to help people identify locally grown foods at farmers markets and elsewhere need to be expanded. A recent study [38] finds that consumers prefer labels as the way to communicate product attributes. Exploration of funding strategies for such identification, such as user fees and sponsorships by commodity groups is needed. Farmers market managers can also create and enforce clear labeling and signage policies to assist customers to easily and confidently identify local food.

These findings suggest directions for additional RMA research, which can parse out differences in specific markets and guide effective marketing strategies. For example, the data results imply a tradeoff between quality, local food and convenience. Customer counts at different days and times, and dot poster surveys geared at measuring preferences for product and attribute mixes, and preferred days/times/locations would inform market managers' decisions.

\section{Conclusions: Future Directions}

This paper reports on the results of a representative survey of Michigan residents regarding their attitudes and behaviors surrounding local food and farmers markets. Findings illuminate key differences in how these markets are perceived by different ethnic groups and point toward themes with which to focus marketing efforts. 
Future research is needed in areas including optimizing labeling efforts and discovering effective tradeoffs between embeddedness and marketness-instrumentalism, e.g., high quality versus price, or relationship with the farmer versus convenience. Conjoint analysis studies could measure part-worths of certain embeddedness/marketness-instrumentalism traits. Efforts to catalogue and compare results of RMAs would greatly increase our understanding of farmers markets. Finally, greater effort is needed to understand and address the obstacles faced by Latino consumers and farmers.

Further research is also needed to understand how farmers markets and locally grown foods can contribute to the overall sustainability of food systems. Many scholars caution that "local" does not unambiguously correspond to virtuous or sustainable $[39,40]$. Others caution that the carbon footprints of local food systems depend critically on efficient distribution [41]. Tradeoffs among the three pillars of sustainability are poorly understood.

We hope this paper contributes to greater understanding of local food and farmers markets, and look forward to efforts which will increase the benefits of these approaches to Michigan and elsewhere.

\section{Acknowledgements}

State funds for this project were matched with Federal funds under the Federal-State Marketing Improvement Program of the Agricultural Marketing Service, U.S. Department of Agriculture.

\section{References and Notes}

1. USDA National Agricultural Statistics Service. The Census of Agriculture; Available online: http://www.agcensus.usda.gov/ (accessed on 9 July 2009).

2. American Farmland Trust. Farming on the Edge Report. What's Happening to Our Farmland? Available online: http://www.farmland.org/resources/fote/default.asp (accessed on 9 July 2009).

3. Conner, D.S.; Knudson, W.A.; Hamm, M.W.; Peterson, H.C. The food system as an economic driver: strategies and applications for Michigan. J. Hunger Environ. Nutrition 2008, 3, 371-383.

4. Lobao, L. Locality and Inequality. Farm Structure and Socioeconomic Conditions; State University of New York Press: Albany, NY, USA, 1990.

5. Welsh, R.; Lyson, T. Anti-Corporate Farming Laws, the "Goldschmidt Hypothesis" and Rural Community Welfare. In Proceedings of the Annual Meeting of the Rural Sociological Society, Albuquerque, NM, USA, August 2001.

6. Lyson, T.A.; Welsh, R. Agricultural industrialization, anticorporate farming laws, and rural community welfare. Environ. Plann. A 2005, 37, 1479-1491.

7. Kirschenmann, F.; Stevenson, S.; Buttel, F.; Lyson, T.; Duffy, M. Why worry about the agriculture of the Middle? In Food and the Mid-Level Farm, Renewing an Agriculture of the Middle; Lyson, T., Stevenson, G.W., Welsh, R., Eds.; MIT Press: Cambridge, MA, USA, 2008; Volume 2005, pp. 3-22.

8. Andreatta, S.; Wickliffe, W. Managing Farmer and Consumer Expectations: A Study of a North Carolina Farmers Market. Hum. Organ. 2002, 61, 167-176.

9. Govindasamy, R.; Italia, J.; Adelaja, A. Farmers Markets: Consumer Trends, Preferences, Characteristics. J. Ext. 2002, 40, 1. 
10. Porter, M.E. Competitive Advantage: Creating and Sustaining Superior Performance; Free Press: New York, NY, USA, 1985.

11. Lancaster, K.L. A New Approach to Consumer Theory. J. Polit. Econ. 1974, 74, 132-157.

12. Michigan Farmers Market Association. About MIFMA; Available online: http://farmersmarkets.anr.msu.edu/AboutUs/AboutMIFMA/tabid/1376/Default.aspx (accessed on 9 July 2009).

13. USDA Economic Research Service. Where Does Your Food Dollar Go? Available online: http://www.ers.usda.gov/Publications/eib48/spreads/17/index.htm (accessed on 9 July 2009).

14. Keeling Bond, J.; Thilmany, D.; Bond, C.A. Direct Market Purchases of Fresh Produce: Understanding Consumer Purchasing Decisions. Choices 2006, 21, 4.

15. Swenson, D. The Economic Impacts of Increased Fruit and Vegetable Production and Consumption in Iowa: Phase II; Regional Food Systems Working Group Leopold Center for Sustainable Agriculture, Iowa State University: Ames, IA, USA, 2006.

16. Conner, D.S.; Levine, R.L. Circles of Association: The Connections of Community-Based Food Systems. J. Hunger Environ. Nutrition 2006, 3, 5-25.

17. Hilchey, D.; Lyson, T.; Gillespie, G.W. Farmers' Markets and Rural Economic Development; Cornell University Farming Alternatives Program: Ithaca, NY, USA, 1995.

18. Cummings, H.; Kora, G.; Murray, D. Community and Economic Impact Of Farmers' Markets in Ontario: Summary Report; School of Rural Planning and Development, University of Guelph: Guelph, ON, USA, 1999.

19. Kotler, P.; Armstrong, G. Principles of Marketing, 7th ed.; Prentice Hall: Englewood Cliffs, NJ, USA, 1996.

20. Hinrichs, C.C. Embeddedness and local food systems: notes on two types of direct agricultural market. J. Rural Stud. 2000, 16, 295-303.

21. Onianwa, O.; Wheelock, G.; Mojica, M., An Analysis of the Determinants of Farmer-to-Consumer Direct-Market Shoppers. J. Food Distrib. Res. 2005, 36, 130-134.

22. Govindasamy, R.; Nayga, R.M., Jr. Characteristics of Farmer-To-Consumer Direct Market Customers: An Overview. J Ext 1996, 34, 4.

23. Wolf, M.M. A Target Consumer Profile and Positioning for Promotion of the Direct Marketing of Fresh Produce: A Case Study. J. Food Distrib. Res. 1997, 28, 11-17.

24. Kezis, A.; Gwebu, T.; Peavey, S.; Cheng, H.-T. A Study of Consumers at a Small Farmers' Market in Maine: Results from a 1995 Survey. J. Food Distrib. Res. 1998, 24, 91-99.

25. Ostrom, M. Consumer Food Purchasing: Interest in Local and Direct Markets; Washington State University: Pullman, WA, USA, 2005.

26. Zepeda, L.; Li, J. Who Buys Local Food? J. Food Distrib. Res. 2006, 37, 1-11.

27. Bean Smith, M.; Sharp, J.S. A Current and Retrospective Look at Local Food Consumption and Support among Ohioans; The Ohio State University: Columbus, OH, USA, 2008.

28. Marinez, J. Michigan State University Extension, East Lansing, MI, USA. Personal communication, 2009.

29. Colasanti, K.J.A.; Conner, D.S.; Smalley, S.B.; Ross, R.B. Increasing farmers market patronage in Michigan: Qualitative results. In Proceedings of the Agriculture, Food and Human Values Society Annual Conference, Penn State University, University Park, PA, USA, 28-31 May 2009. 
30. Alkon, A. Whiteness and Farmers Markets. Performances, Perpetuations...Contestations? Antipode (in press).

31. Allen, P. Together at the Table, Sustainability and Sustenance in the American Agrifood System; The Pennsylvania State University Press: University Park, PA, USA, 2004.

32. DeLind, L. Market Niches, "Cul de Sacs", and Social Context: Alternative Systems of Food Production. Cult. Agr. 1993, 13, 7-12.

33. Lev, L.; Brewer, L.; Stephenson, G. Tools for Rapid Market Assessment; Oregon State University Extension Service: Corvallis, OR, USA, 2008.

34. Hembroff, L. Methodological Report, Michigan State University State of the State Survey; Institute for Public Policy and Social Research Office for Survey Research, Michigan State University: East Lansing, MI, USA, 2009.

35. Selfa, T.; Qazi, J. Place, Taste, or Face-to-Face? Understanding Producer-Consumer Networks in "Local" Food Systems in Washington State. Agr. Hum. Values 2005, 22, 451-464.

36. Conner, D.S.; Montri, A.; Montri, D.; Hamm, M.W. Consumer demand for local produce at extended season farmers' markets: guiding farmer marketing strategies. Renew. Agr. Food Syst. 2009, 24, 251-259.

37. Zepeda, L.; Leviten-Reid, C. Consumers' Views on Local Food. J. Food Distrib. Res. 2004, 35, $1-6$.

38. Howard, P.H. Central coast consumers want more food-related information, from safety to ethics. Calif. Agr. 2006, 60, 14-19.

39. Bellows, A.C.; Hamm, M.W. Local Autonomy and Sustainable Development: Testing Import Substitution in Local Food Systems Agr. Hum. Values 2001, 18, 271-284.

40. Born, B.; Purcell, M. Avoiding the Local Trap. J. Plan. Educ. Res. 2006, 26, 195-207.

41. Oglethorpe, D.R. Local Food-Miles Better? Eur. Supply Chain Manage. 2008, 1, 12-15.

(C) 2010 by the authors; licensee Molecular Diversity Preservation International, Basel, Switzerland. This article is an open-access article distributed under the terms and conditions of the Creative Commons Attribution license (http://creativecommons.org/licenses/by/3.0/). 